\title{
Expert System for Identifying Weeds on Oil Palm Plantations Using a Web Based Forward Chaining and Dempster Shafer Method
}

\author{
Hastuti \\ Software Engineering Technology, \\ Agriculture Polytechnic of \\ Samarinda, 75242, Indonesia \\ tutihastuti657@gmail.com
}

\author{
Eny Maria (i)* \\ Software Engineering Technology, \\ Agriculture Polytechnic of \\ Samarinda, 75242, Indonesia \\ enymaria@politanisamarinda.ac.id \\ *Corresponding Author
}

\author{
Annafi Franz \\ Software Engineering Technology, \\ Agriculture Polytechnic of \\ Samarinda, 75242, Indonesia \\ annafifranz@gmail.com
}

Submitted: 2021-10-05; Revised: 2021-10-30; Accepted: 2022-01-01; Published: 2022-03-01

\begin{abstract}
- an expert system for identifying weeds on oil palm plantations using a web-based forward chaining and dempster shafer method. Palm oil is one of the plants that has its own charm in the community because the commodity of palm oil plays an important role in the Indonesian economy, therefore demand for palm oil continues to increase. Along with the increasing demand for palm oil in the world market, oil palm plantations have experienced many disturbances, one of which is weeds which are very detrimental to oil palm farmers, so oil palm farmers are trying to control it. Therefore, the purpose of this research is to build a system application that can be used by farmers to provide information related to weeds that attack oil palm and their control solutions.
\end{abstract}

Keywords-Oil palm, Weed, Forward chaining, Dempster shafer

\section{INTRODUCTION}

Oil palm plantations are one of the foundations for the growth and development of the oil palm agribusiness system. Palm oil commodity plays an important role in the Indonesian economy because this commodity has bright prospects as a source of foreign exchange. The demand for palm oil continues to increase, besides being used as a raw material for the food industry, it is also used as a raw material for the non-food industry. When viewed from the cost of production, palm oil commodity is much better than other vegetable oils. Palm oil is a plantation product that has bright prospects in the future. The potential in the diversity of uses of palm oil. The oil palm agribusiness sector has a positive impact on national development. In the process of development, the area of oil palm plantations in Indonesia also increased in 2009 from 7.8 million ha to 8.3 million ha in 2010 . Along with the increasing demand for palm oil in the world market, oil palm plantations have experienced many disturbances, one of which is weeds are very detrimental to oil palm farmers, so oil palm farmers are trying to control it. The presence of weeds in plantations can reduce production because weeds compete with cultivated plants for groundwater, sunlight, nutrients, air and growing space.
This causes the growth of cultivated plants to be disrupted, so that it can reduce production yields. In addition, weeds can also reduce the quality of crop yields due to contamination with weed parts. Weeds can also be a host for pests and pathogens that attack plants, interfere with water use, release allelopathic compounds that can interfere with plant growth and increase farming costs. The presence of many weeds has a negative impact on plantation business, for this reason, it is necessary to have regular and planned weed management (Manullang, 2013) .

Lack of information known by oil palm farmers about the types of weeds that attack oil palms and how to control weeds properly. If this is allowed to continue, it will have an impact on the level of production in oil palm plantations. Oil palm farmers need a tool that can provide information and solutions regarding invading weeds.

Based on the description of the problem, the author decided to take the title "an expert system for identifying weeds on oil palm plantations using a web-based forward chaining and dempster shafer method" in this research.

The purpose of this study is to build a system application that can be used to identify weeds on oil palm plantations, by providing good answers and conclusions.

The expected result in this final project is to build a system application that can make it easier for farmers to identify weeds on oil palm plantations.

\section{LITERATURE REVIEW}

\section{A. Study Literature}

In the research of (Zahrul et al., 2018) with the title "Koi Fish Disease Diagnosis System Using Forward Chaining and Dempster Shafer Methods". Forward Chaining and Dempster Shafer methods can be applied to systems for diagnosing diseases in Koi fish by providing information criteria regarding symptoms, types of diseases, and solutions for preventing koi fish diseases resulting from interviews with experts and supported by several other relevant references such as books and papers. Looking for a set of facts about a symptom given by the user as system input using the Forward Chaining Method. After getting the weight value, a hypothesis 
consisting of 2 parts is carried out, namely the calculation process using the Dempster Shafer and the analysis of the hypothesis which is the result of the final calculation, and then used as a conclusion.

In the research of (Alamsyah, 2018) with the title "Web-Based Expert System to Determine the Distribution of Inheritance According to Islamic Law Using Forward Chaining and Dempster Shafer Methods". This system provides more accurate decisions using forward chaining and dempster shafer methods based on the trust of an expert. In the Dempster Shafer theory, it is known that there is a Frame of Discernment which is denoted by . This frame is the universe of conversation from a set of hypotheses $=\{\mathrm{A}, \mathrm{B}, \mathrm{D}, \mathrm{E}\}$. The goal is to relate the confidence measure of the elements. Not all evidence directly supports each element. Based on the testing of this system, which is $92.67 \%$, which means this system can run well because the results of the system are close to the similarities with the actual field facts.

In (Rahmanita et al., 2019) with the title "Expert System for Diagnosing Gastrointestinal Diseases with Comparison of Forward Chaining and Dempster Shafer Methods". Based on the research that has been carried out in the manufacture of an expert system for diagnosing digestive tract diseases by comparing the forward chaining and dempster shafer methods, it can be concluded that the testing of the system that was tried directly by the expert based on 35 data that has been tested has a fairly good success rate according to the expert diagnosis. Which is $71 \%$. And it can be seen that the Dempster Shafer method is better because the Dempster Shafer method has a calculation process algorithm so that when analyzing a problem a percentage of accuracy will be generated.

In the research of (Laely et al., 2020) with the title Expert System for Diagnosing Chili Diseases with Forward Chaining and Dempster Shafer Methods. In this study, the researchers created a system that can be used to diagnose diseases in chili plants. The methods used are forward chaining and the dempster shafer method to calculate the value of confidence or accuracy in chili plant diseases that have been diagnosed.

In (Putri \& Aranta, 2020), with the title Expert system for diagnosing rice plant diseases using forward chaining and dempster shafer. In this expert system the use of the forward chaining method was chosen because the method is more appropriate to use if the facts given are more than the conclusions to be concluded, while the dempster shafer method is chosen because this method can provide additional information in the form of a percentage level of confidence in an object.

In (MZ et al., 2020), with the title Expert System for Diagnosing Skin Diseases in Humans with the Dempster Shafer Method. Diseases and disorders of the skin can be caused by various factors, including infection microorganisms, immunity, allergic reactions and environmental and personal health. Skin that getting sick will have many consequences including itching, the skin can not feel anything also, skin function failure, interfere with appearance an patient's activity. Expert system can help to solve problem with collecting and storing expert knowledge in the later knowledge base reason like an expert in make decisions. One of the methods on the system the expert is Dempster Shafer.

\section{B. Oil Palm and Weed}

a) Oil Palm

Oil palm is one of the main plantation commodities in Indonesia. Palm oil has played an important role in Indonesia's economy and development. Agricultural exports have a positive influence on national income. According to data compiled by the Directorate General of Plantations, Indonesia's palm oil export volume in 2013 reached 20_572_200 tons, which was valued at 15.8 trillion USD. Oil palm plantations are also able to create jobs so as to increase the welfare of the community. Based on data compiled by the Directorate General of Plantations, the total area of coconut plantations in 2013 reached 9_149_919 hectares (Zaman, 2016)

b) Weed

Weeds are plants that grow where you don't want it by humans or plants its use is unknown. The presence of weeds in the plantation can reduce production due to weeds compete with plants power in fighting over groundwater, light sun, nutrients, air and growing space. This results in cultivated plants disrupted growth, so it can reduce production. Besides, weed can also reduce the quality of crop yields as a result of contamination with parts weed. Weeds can also be a host for pests and pathogens that attack plants, interfere with water use, remove allelopathic compounds that can interfere with plant growth and increase costs farming. There are many weeds have a negative impact on business plantations, for that there is a need for management regular and planned weeds (Nufvitarini et al., 2016)

\section{Expert System}

Expert system (expert system) is a branch of Artificial Intelligence (AI) which is quite old because this system was developed in the mid 1960s. The expert system that first appeared was the General purpose problem solver (GPS) developed by Newel and Simon. The term expert system comes from the term knowledge-based expert system. This term arises because to solve problems, Expert Systems use the knowledge of an expert that is entered into the computer. Someone who is not an expert uses the Expert System for a knowledge assistant. Expert system is a system that uses human knowledge where the knowledge is entered into a computer and then used to solve problems that usually require human expertise or expertise (Dewi et al., 2012).

\section{Forward Chaining}

Forward Chaining is a method of searching/drawing conclusions based on existing data or facts towards a conclusion, the search starts from the existing facts and 
then moves forward through the premises to reach a conclusion (bottom up reasoning).

\section{E. Dempster Shafer}

Dempster Shafer is the representation, combination and propagation of uncertainty, where this theory has several characteristics that are intuitively in accordance with the way of thinking of an expert, but a strong mathematical basis. The Dempster Shafer method was first introduced by Dempster, who conducted an uncertainty model experiment with a range of probabilities as a single probability. Then in 1976 Shafer published Dempster theory in a book entitled Mathematical Theory of Evident. In general, the Dempster Shafer theory is written in an interval [Belief, Plausibility]. Belief is a measure of the strength of evidence in supporting a set of propositions. If it is worth 0 (zero) then it indicates that there is no evidence, and if it is worth 1 it indicates certainty. According to Giarratano and Riley, the belief function. (1)

$\operatorname{Bel}(X)=\sum_{Y C X} m(Y)(1)$

and Plausibility is denoted by the (2)

$\operatorname{Pis}(X)=1-\operatorname{Bel}(X)=1-\sum_{Y C X}^{n} m(X)(2)$

Description:

$\operatorname{Bel}(X)=\operatorname{Belief}(X)$

$P l s(X)=$ Plausibility $(X)$

$m(X)=$ mass function from $(X)$

$m(Y)=$ mass function from $(Y)$

The Dempster Shafer theory states that there is a frame of discernment denoted by the symbol $(\Theta)$. The frame of discernment is the universe of talks from a set of hypotheses. So it is often referred to as the environment, namely (3)

$\Theta=\{\theta 1, \theta 2, \theta \mathrm{N}\}(3)$

Description:

$\Theta=$ frame of discernment or environment

$\theta 1,, \theta N=$ element environment

The environment contains elements that describe the possible answers, and there is only one that will match the required answer. This possibility in Dempster Shafer theory is called a power set and is denoted by $\mathrm{P}(\Theta)$, each element in this power set has an interval value between 0 to 1. (4)

$m: P(\Theta)[0,1](4)$

So that it can be formulated (5)

$\sum_{X e P(\theta)} \mathrm{m}(\mathrm{X})=1(5)$

Description:

$P(\Theta)=$ power set

$m(X)=$ mass function $(X)$

Mass function ( $m$ ) in the Dempster shafer theory is the level of confidence of an evidence (symptom), often referred to as an evidence measure so it is denoted by (m). The goal is to relate the confidence measure of the elements of . Not all evidence directly supports each element. For this reason, it is necessary to have a probability density function $(\mathrm{m})$. The value of $m$ defines not only the elements of, but also all of its subsets. So if contains $n$ elements, then the subset of is $2 n$. The sum of all $\mathrm{m}$ in the subset is equal to 1 . If there is no information whatsoever to choose a hypothesis, then the value (6)

$\mathrm{m}\{\theta\}=1.0$. (6)

If it is known that $\mathrm{X}$ is a subset of, with $\mathrm{m} 1$ as a density function, and $\mathrm{Y}$ is also a subset of with $\mathrm{m} 2$ as a density function, then a combination function of $\mathrm{m} 1$ and $\mathrm{m} 2$ can be formed as $\mathrm{m} 3$.

The formula of the Dempster Shafer theory (7)

$$
m 3(Z)=\frac{\sum x \cap Y=z m 1(X) \cdot m 2(Y)}{1-\sum x \cap Y=\theta m 1(X) \cdot m 2(Y)}
$$

Description:

$m 1=$ density for the first symptom

$m 2=$ density of second symptom

$m 3=$ combination of the two densities above

$\theta=$ universe of speech from a set of hypotheses $\left(X^{\prime}\right.$ and $\left.Y^{\prime}\right)$

$X^{\prime}$ and $Y^{\prime}=$ Subset of

\section{F. Black Box Testing}

Black box Testing is one of the techniques focused software testing on the functional specifications of the device soft. With Black box Testing enable device developers software to create a collection of a the state of the input in a program that will train all the conditions functional (Yani et al., 2020)

\section{RESEARCH METHODS}

\section{A. Research Procedure}

The research procedure is a step that will be carried out by the author to make it easier to conduct research can be seen in Picture 1.

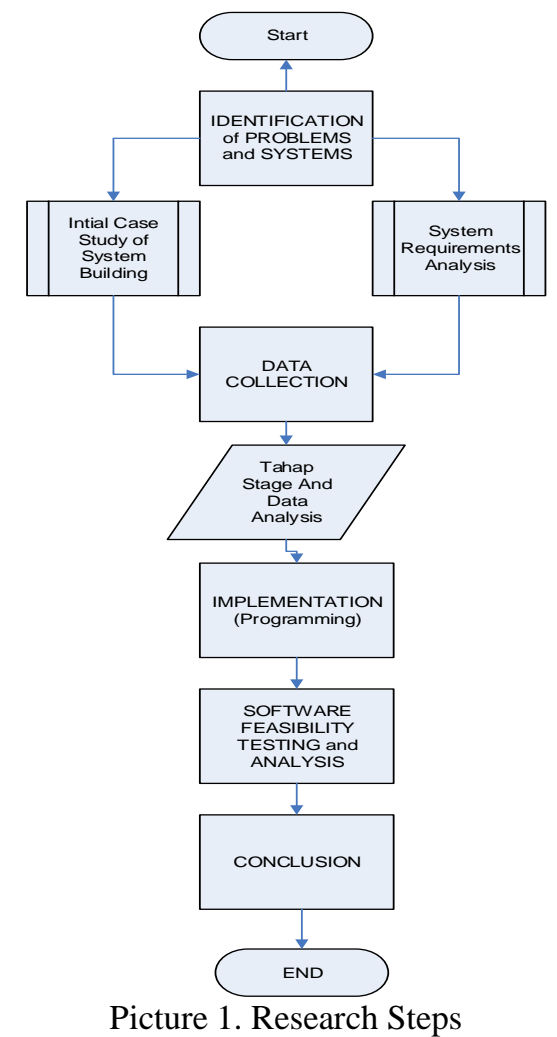

Picture 1. Research Steps 
The steps of the research procedure are as:

1. Identification of Problem and Systems

Identifying a problem which is an early stage in the research process. This stage is done so that research can actually find scientific problems. This stage is built based on the formulation of the problem based on the background of the problem. Understand the theories used and look for the factors that are the requirements of an Expert System for Weed Identification on Oil Palm Plantations by collecting literature studies such as national or international journals, reading books and browsing the internet. The system identification stage is carried out to meet the system needs both data, hardware and software.

2. Data Collection

This stage is a way of collecting data which is done by interviewing experts.

3. Programming

This stage is the stage of building a system according to the problems obtained previously, designing a system design or model and implementing the Forward Chaining and Dempster Shafer method, into the program to be created.

4. System Testing

This is the stage of testing the system that has been successfully created and also analyzing the feasibility of the system.

5. Conclusion

It is the final stage of the description of the research process by concluding the existing problems.

\section{B. Analysis Model}

The software process flow representation model to be designed is presented in a Context Diagram (CD). $\mathrm{Cd}$ is used to describe the flow of information and data processes that move from data input to output. The CD makes it easier for users who are less familiar with the computer field to understand the system to be worked on or developed. Can be seen in Picture 2.

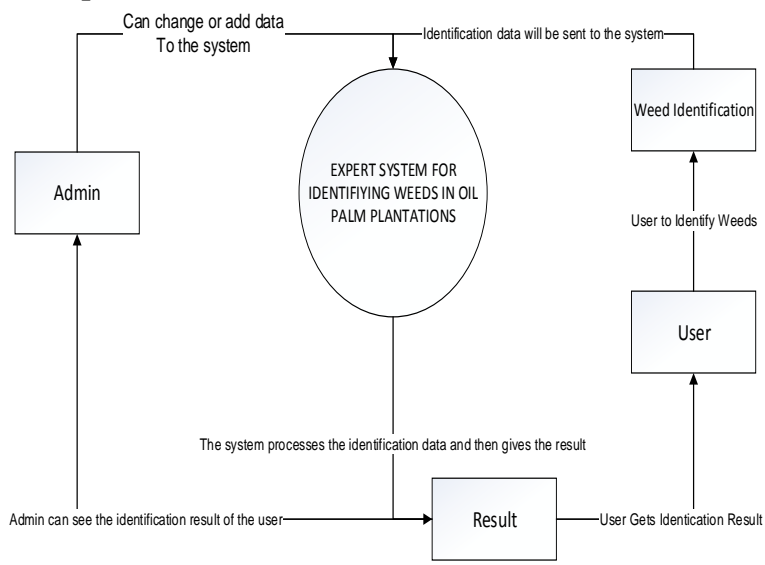

Picture 2. Context Diagram

Context Diagram consists of 2 (two) entities, namely the expert (Admin) and the user (user). Admin provides input to the system in the form of weed name data and weed characteristics. The user in identifying weeds gives characteristics to the system which are facts and then, the system gives the appropriate identification results.

\section{RESULTS AND DISCUSSION}

The following is a display of the results of the application of the Weed Identification Expert System on Oil Palm Plantation Using Forward Chaining and WebBased Dempster Shafer Methods.

1. Home Menu

The Home screen is the first display that appears when entering the expert system for identifying weeds on oil palm plantations. Can be seen in Picture 3.

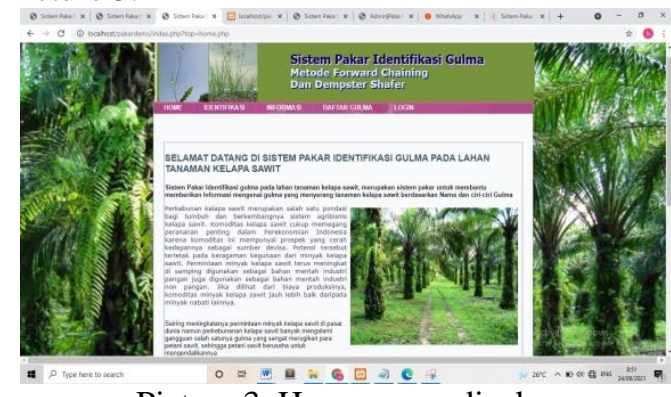

Picture 3. Home menu display

2. User registration menu

On this page the user can directly register so that the user can carry out the weed identification process. Can be seen in Picture 4.

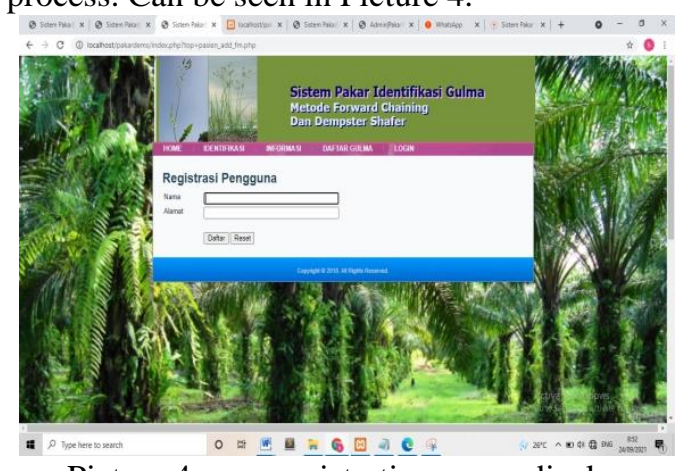

Picture 4. user registration menu display

3. Identification process display

On this page displays the weed identification process, the user can directly select the characteristics of the weeds. Can be seen in Picture 5.

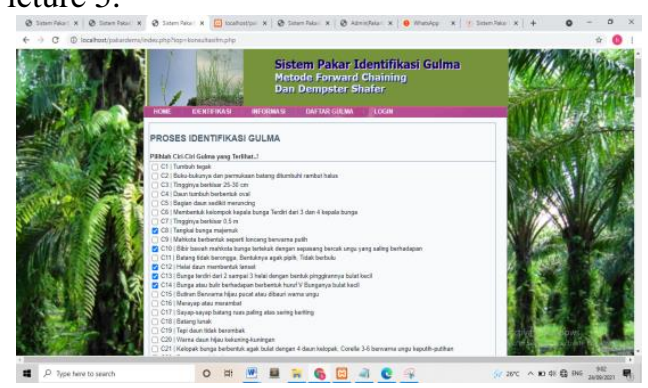

Picture 5. Identification process menu display

4. Display of weed identification results 
Is a page of Weed Identification Results which is obtained from the initial calculations and the results of the calculation of the weed expert system in oil palm. Can be seen in Picture 6.

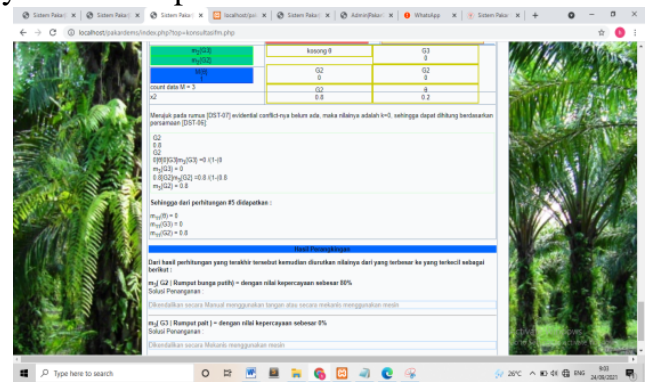

Picture 6. Display of weed identification results

6. Information menu display

An information menu page, on this page there is information about how to use the system. Can be seen in Picture 7.

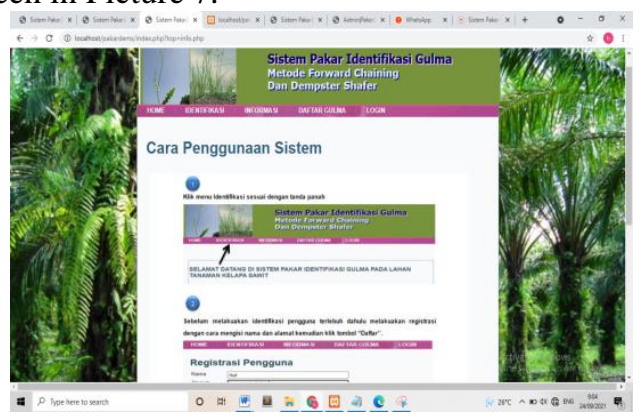

Picture 7. Information menu display

7. Weed list menu display

Is a menu page that displays details of weeds and the types of weeds contained in the system. Shown in Picture 8.

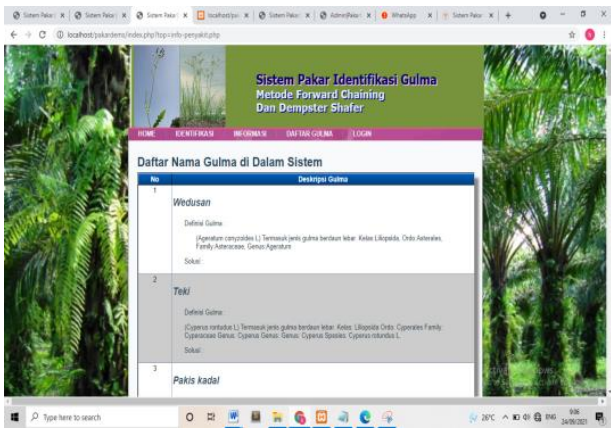

Picture 8. Weed list menu display

8. Login view

Login view is a menu for admins who want to cultivate an expert system, admins can access the list of weeds and solutions, characteristics of weeds, rules, and reports of weed characteristics. Can be seen in Picture 9.

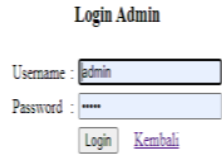

\section{Picture 9. Login view}

9. Home screen after admin login This is the main view after admin login where admin can add data, edit and delete data. Can be seen in Picture 10.

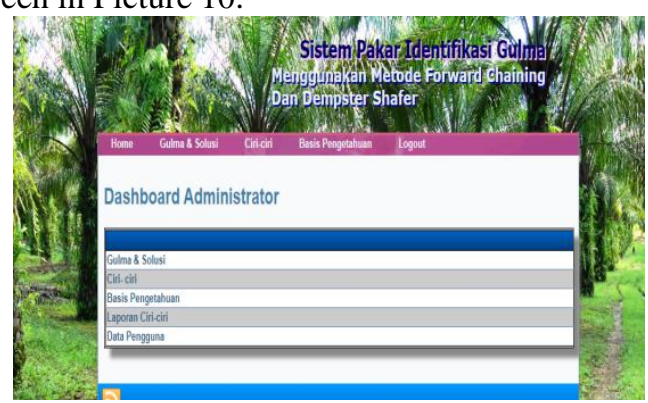

Picture 10. Home screen after admin login

Black-Box Testing is a software testing technique that focuses on the functional specifications of the software To find errors in the system, the black box testing method is used. The results of the bias system test are shown in Table 1.

Table 1. System testing

\begin{tabular}{|c|c|c|}
\hline Input & Output & Test Result \\
\hline $\begin{array}{l}\text { Click the Home } \\
\text { menu }\end{array}$ & Show main page & Succeed \\
\hline $\begin{array}{l}\text { Click the } \\
\text { Identification menu }\end{array}$ & $\begin{array}{l}\text { Show identification } \\
\text { page }\end{array}$ & Succeed \\
\hline $\begin{array}{l}\text { Click the Information } \\
\text { menu }\end{array}$ & $\begin{array}{l}\text { Displaying information } \\
\text { on how to use the } \\
\text { system }\end{array}$ & Succeed \\
\hline $\begin{array}{l}\text { Click the Weed list } \\
\text { menu }\end{array}$ & $\begin{array}{l}\text { Display a list of weed } \\
\text { names }\end{array}$ & Succeed \\
\hline $\begin{array}{l}\text { Click the Login } \\
\text { menu }\end{array}$ & Show admin login page & Succeed \\
\hline $\begin{array}{l}\text { Click the Login } \\
\text { Button }\end{array}$ & Show admin menu & Succeed \\
\hline $\begin{array}{l}\text { Click the Weeds and } \\
\text { Solutions menu }\end{array}$ & $\begin{array}{l}\text { Displays a list of weed } \\
\text { names and their control } \\
\text { solutions }\end{array}$ & Succeed \\
\hline $\begin{array}{l}\text { click the weed } \\
\text { feature menu }\end{array}$ & $\begin{array}{l}\text { Displays a list of weed } \\
\text { characteristics }\end{array}$ & $\begin{array}{l}\text { Succeed } \\
\text { Succeed }\end{array}$ \\
\hline $\begin{array}{l}\text { Click Knowledge } \\
\text { Base }\end{array}$ & $\begin{array}{l}\text { Show knowledge base } \\
\text { page }\end{array}$ & \\
\hline $\begin{array}{l}\text { Click the Logout } \\
\text { menu }\end{array}$ & $\begin{array}{l}\text { Exit the admin menu } \\
\text { page and come back } \\
\text { to main page }\end{array}$ & Succeed \\
\hline Click the Edit button & $\begin{array}{l}\text { Showing the data edit } \\
\text { page }\end{array}$ & Succeed \\
\hline $\begin{array}{l}\text { Click the delete } \\
\text { button }\end{array}$ & Can delete data & Succeed \\
\hline Click the Save button & Can save data & Succeed \\
\hline
\end{tabular}




\section{CONCLUSION}

The conclusions from the results of the design and implementation of an expert system for identifying weeds on oil palm plantations using web-based forward chaining and dempster shafer methods are as follows, based on the results of the response, it can be concluded that this application makes it easier for users to answer or identify weeds that attack oil palm plantations and their control solutions.

Based on the conclusions above, the authors provide suggestions for the development of this application or system in the future is, this application can be developed to diagnose diseases of other types of plants and making this system can be developed in the form of other applications, for example, an Android-based application can be made.

\section{References}

Alamsyah, D. P. (2018). Sistem Pakar Berbasis Web Untuk Menentukan Pembagian Harta Waris Menurut Hukum Islam Menggunakan Metode Forward Chaining Dan Jurnal Pengembangan Teknologi Informasi Dan Ilmu Komputer. ... Teknologi Informasi Dan Ilmu Komputer E ..., 2(2), 510-514. Http://J-Ptiik.Ub.Ac.Id/Index.Php/JPtiik/Article/View/866

Dewi, E., Mulyani, S., \& Restianie, I. N. (2012). Aplikasi Sistem Pakar Untuk Mendiagnosa Penyakit Anak (Balita) Dengan Menggunakan Metode Forward Chaining. 1(1), 6-7.

Laely, M., Wijaya, I. G. P. S., \& Aranta, A. (2020). Sistem Pakar Diagnosis Tanaman Cabai Dengan Metode Forward Chaining Dan Dempster Shafer. Jurnal Teknologi Informasi, Komputer, Dan Aplikasinya (JTIKA ), 2(2), 268-279. Https://Doi.Org/10.29303/Jtika.V2i2.118

Manullang, R. R. (2013). Identifakasi Dan Dominasi Gulma Pada Lahan Tanaman Kelapa Sawit Eks Lahan Tanaman Pisang, Ilalang Dan Semak Belukar Di Perkebunan Rakyat Pola Pir Swadya Kecamatan Muara Badak. Tesis. Pertanian Tropika Basah. Program Pasca Sarjana, Universitas Mulawarman, .

MZ, A. R., Wijaya, I. G. P. S., \& Bimantoro, F. (2020). Sistem Pakar Diagnosa Penyakit Kulit Pada Manusia Dengan Metode Dempster Shafer. Journal Of Computer Science And Informatics Engineering (J-Cosine), 4(2), 129-138. Https://Doi.Org/10.29303/Jcosine.V4i2.285

Nufvitarini, W., Zaman, S., \& Junaedi, A. (2016). Pengelolaan Gulma Kelapa Sawit (Elaeis Guineensis Jacq.) Studi Kasus Di Kalimantan Selatan. Buletin Agrohorti, 4(1), 29-36. Https://Doi.Org/10.29244/Agrob.V4i1.14997

Putri, D. A., \& Aranta, A. (2020). Sistem Pakar
Diagnosis Penyakit Tanaman Padi Menggunakan Forward Chaining Dan Dempster Shafer. Jurnal Teknologi Informasi, Komputer, Dan Aplikasinya (JTIKA ), 2(2), 248-257. Https://Doi.Org/10.29303/Jtika.V2i2.113

Rahmanita, E., Agustiono, W., \& Juliyanti, R. (2019). Sistem Pakar Diagnosa Penyakit Saluran Pencernaan Dengan Perbandingan Metode Forward Chaining Dan Dempster Shafer. Jurnal Simantec, $7(2)$, 82-89. Https://Doi.Org/10.21107/Simantec.V7i2.6743

Yani, A., Setiawan, D., Sofian, N. E., Subagja, R., \& Desyani, T. (2020). Pengujian Aplikasi Reservasi Hotel Di Legreen Hotel \& Suite Dengan Metode Black Box Testing Boundary Value Analysis. Jurnal Teknologi Sistem Informasi Dan Aplikasi, 3(2), 114. Https://Doi.Org/10.32493/Jtsi.V3i2.4686

Zahrul, M. M., Santoso, E., \& Rahayudi, B. (2018). Sistem Diagnosis Penyakit Ikan Koi Menggunakan Metode Forward Chaining Dan Dempster-Shafer. Jurnal Pengembangan Teknologi Informasi Dan Ilmu Komputer, 2(8), 2886-2891.

Zaman, H. P. Dan S. (2016). Pengendalian Gulma Perkebunan Kelapa Sawit (Elaeis Guineensis Jacq.) Di Perkebunan Padang Halaban, Sumatera Utara. 4(1), 87-93. 